\title{
Phiri, the plight of the poor and the perils of climate change: time to rethink environmental and socio-economic rights in South Africa?
}

\author{
Louis J Kotzé* \\ Professor of Law, North West University, South Africa
}

\begin{abstract}
South Africa is a water-stressed country where scarce water resources are unequally available to South Africans. It seems inevitable that climate change will in future severely affect the availability of water resources and the ecological and socio-economic aspects of water uses in the country. It is especially the poor, indigent and marginalized sectors of the population that have inadequate access to water and it is these people who would also be most severely affected by the impact of climate change on water resources. While South African constitutional and statutory provisions guarantee everyone access to sufficient water, an environmental right and other laws simultaneously aim to protect water resources. There is accordingly a very real possibility for sustainability conflicts to arise where difficult decisions have to be made with respect to providing people access to sufficient water on the one hand and protecting water resources for the benefit of present and future generations on the other. The latter conflict was recently illustrated in the Constitutional Court judgment of Mazibuko v City of Johannesburg 2009 JDR 1030 (CC). For the first time, South Africa's highest Court was required to provide content to the constitutionally entrenched right of access to sufficient water. Against a general discussion of the state of water resources in South Africa, the predicted impact of climate change on these resources and the prevailing socio-economic conditions in the country, this article analyses the Court's decision in Mazibuko and argues that its restrictive interpretation of the right to access to water could be considered ecologically responsible and conducive to achieving inter-generational equity.
\end{abstract}

Keywords: water resources, access to water, climate change, poverty, sustainability, constitution, socio-economic rights, environmental rights

The problem of water scarcity in South Africa is essentially one of conflict between: different uses and users, present and future generations, the application of human and capital resources for water resource development relative to other investments, and economic prosperity and preservation of ecosystems. These conflicts should be resolved through

* Parts of this article were completed during a research visit to the Australian Centre for Environmental Law (ACEL), at the University of Sydney during November 2009. My sincere thanks to ACEL's Director, Professor Rosemary Lyster, and her colleagues for accommodating me during my stay. I am also indebted to Professors Loretta Feris (UCT) and Anel du Plessis (NWU), Professor Emeritus Alan Brimer, Miss Debra Horsten (NWU), the anonymous reviewers and the editors for their insightful comments on an earlier draft of this article. All opinions expressed herein and all errors remain those of the author. 
interventions to ensure that water resources are protected, used, developed, conserved, managed and controlled in such a way as to achieve optimum long-term environmentally sustainable, social and economic benefit for society. ${ }^{1}$

\section{INTRODUCTION}

Notwithstanding the many meanings attributed to it, for me personally, sustainability has always been best understood as an approach to resolving conflicts between the most basic (socio-economic) conditions of human existence on the one hand, and ecological interests on the other. ${ }^{2}$ More of the one usually implies less of the other, unless an acceptable compromise is found which affords equal importance to ecological, social and economic interests. In an ideal world, one would like every person on earth to be financially secure, well-fed and healthy and to live in safe and comfortable homes close to their places of work, whilst all of this should occur in pristine natural environments with abundant resources available in order to fully enjoy life. Moreover, one would like to see these conditions continuing ad infinitum for the unqualified enjoyment of all of the people who will inhabit the earth in future. Unfortunately we do not live in an ideal world. The harsh reality is that, as far as 'development' in its broadest sense is concerned, we seem to be irreversibly set on an unsustainable path with very little cognizance of the short-, medium- and long-term effects of our activities on the environment.

There are, however, some legal responses and interventions that have been designed to counter the destructive effect of human activities on the environment with a view, primarily, to providing an environment conducive to human health and well-being. One of these is a rights-based approach to environmental protection, and many constitutions the world over now provide for such an environmental right. ${ }^{3}$ Some, especially the constitutions of developing-world countries, also provide for socio-economic rights. The Constitution of the Republic of South Africa, 1996 (the Constitution) is a prime example in this respect, since section 24 provides for an environmental right while section 27 , among other rights, provides for socioeconomic rights; specifically the right of access to sufficient water. ${ }^{4}$ Section 27 states, inter alia, that:

27(1) Everyone has the right to have access to -

...

(b) sufficient food and water; and

...

(2) The state must take reasonable legislative and other measures, within its available resources, to achieve the progressive realization of each of these rights....

1. H Thompson, Water Law: a Practical Approach to Resource Management and the Provision of Services (Juta, Cape Town 2005) 7.

2. An unashamedly anthropocentric view, but perhaps justified in an academic paradigm deriving from the context of a developing country.

3. See T Winstanley, 'Entrenching Environmental Protection in the New Constitution' (1995) 2 South African Journal of Environmental Law and Policy 87.

4. See AL Magaziner, 'The Trickle Down Effect: the Phiri Water Rights Application and Evaluating, Understanding, and Enforcing the South African Constitutional Right to Water' (2008) 33 NCJ Int'L L \& Com Reg at 510 and also the discussion below. 
Human rights are traditionally grouped into two mainstream categories: political and civil rights on the one hand, and socio-economic and cultural rights on the other. ${ }^{5}$ Environmental rights are classified as civil and political rights, ${ }^{6}$ while rights guaranteeing access to water, for example, would constitute socio-economic rights. ${ }^{7}$ This traditional classification fits neatly with the ideal of sustainability in the sense that these rights, as is the case with sustainability, also aim to respect, protect, and promote ecological interests on the one hand, while doing the same for socio-economic interests on the other. Human rights in this sense should therefore also aim to support and strengthen each other rather than being in conflict. ${ }^{8}$ In other words, environmental rights should support socio-economic rights and vice versa. In typical humanist and liberalist fashion, and in keeping with the principal goal of human rights, this would arguably ensure an optimal level of protection for the inborn and inalienable environmental and socio-economic claims of all. ${ }^{9}$

Achieving the latter, however, may be more problematic than it appears. How does one protect the environment by means of an environmental right when one must also simultaneously provide people with access to sufficient water, especially where people are constitutionally entitled to such access by virtue of socio-economic rights? ${ }^{10}$ Water, after all, is one of the three basic environmental media one seeks to protect by means of the environmental right, but in fulfilling the dictates of the right, one could also increase pressure on the resource, thereby possibly hampering any positive effect resulting from the declaration of the right. The challenge is compounded by various socio-economic and environmental factors such as pervasive poverty and profound intra-generational inequities in the context of a developing country. ${ }^{11}$ It is also clear that some of the most significant impacts resulting from environmental phenomena, such as climate change, will be on water resources which, as a consequence, will have a very palpable effect on (a) the ecological aspects of the resource, specifically with respect to water quantity and quality; and as a consequence of the latter, (b) the manner in which water will be provided to people, especially with respect to the poor

5. F Venter, Constitutional Comparison: Japan, Germany, Canada and South Africa as Constitutional States (Juta, Cape Town 2000) 130 et seq.

6. In terms of political and civil rights there rests a 'negative' obligation on the state not to infringe these rights. This could be achieved by, for example, limiting the exercise of state power.

7. Socio-economic rights place a positive obligation on the state to realize certain 'material conditions for human welfare', as Brand puts it, and in this sense they are transformative. See D Brand, 'Introduction to Socio-economic Rights in the South African Constitution' in D Brand and C Heyns (eds), Socio-economic Rights in South Africa (Pretoria University Law Press, Pretoria, 2005) 3.

8. This is consistent with the notion of 'interdependency' of human rights which proposes that human rights should be treated holistically with the view to protection human well-being. S Liebenberg, 'Chapter 33: the Interpretation of Socio-economic Rights' in M Chaskalson et al. (eds), Constitutional Law of South Africa ( $2^{\text {nd }}$ edn Juta Original Service, 2003) 33-1; $\mathrm{S}$ Liebenberg and B Goldblatt, 'The Interrelationship between Equality and Socio-economic Rights under South Africa's Transformative Constitution' (2007) 23 SAJHR 335-61 at 338-9.

9. AA Du Plessis, Fulfilment of South Africa's Constitutional Environmental Right in the Local Government Sphere (Wolf Legal Publishers, Nijmegen 2009) 15.

10. For a discussion of the socio-economic dynamics of the South African environmental right, see LA Feris and D Tladi, 'Environmental Rights' in Brand and Heyns (n 7) 249-64.

11. See generally, P Bond, Unsustainable South Africa: Environment, Development and Social Protest (University of Natal Press, Pietermaritzburg 2002). 
and indigent who have no or inadequate access to this socio-economic entitlement. The ideal of course would be to achieve sustainability, ie an optimal balance between water resource protection (the ecological context) and socio-economic empowerment by providing people with access to sufficient water (the socio-economic context). ${ }^{12}$ All of these challenges raise the following question, which is also the principal focus of this article: considering that the right of access to sufficient water would arguably place increased pressure on an already limited resource that is protected by the environmental right, what then should the role of socio-economic rights be in the South African constitutional state as far as sustainability is concerned, especially in the light of the increasing pressures resulting from climate change on water resources?

The subtle role that socio-economic rights could play in environmental governance efforts was recently highlighted by the South African Constitutional Court in the much-debated case of Mazibuko v City of Johannesburg ${ }^{13}$ (hereafter Mazibuko $v$ City of Johannesburg). ${ }^{14}$ Instituted by Lindiwe Mazibuko and other poor residents of a township near Johannesburg, the case commenced in the High Court (Mazibuko and others $v$ City of Johannesburg and others (Centre on Housing Rights \& Evictions as amicus curiae ${ }^{15}$ and was later appealed to the Supreme Court of Appeal (City of Johannesburg $v$ L Mazibuko). ${ }^{16}$ The case was ultimately decided in the Constitutional Court on 8 October 2009. The central issue before all three courts was the interpretation of section 27 of the Constitution, ie of the content of the constitutional obligation on the state to provide people with access to sufficient water. The trilogy of hearings has received considerable attention from national and international audiences because it is the first case to judicially test, comprehensively interpret, and give practical content to the right of access to water. ${ }^{17}$ This article focuses on the Constitutional Court decision, which has been criticized by some commentators ${ }^{18}$ especially insofar as they consider that, by following a conservative and at times positivistic approach with respect to the interpretation of section 27, South Africa's highest court in constitutional matters did not adequately address the plight of the poor residents of the Phiri township of which Mrs Lindiwe Mazibuko was a resident. ${ }^{19}$ Mindful of Keightley's ${ }^{20}$ warning that one must 'look beyond ... disappointment' and rather be constructive in instances where a 'court ... fails to come to the aid of the poor and vulnerable' as it seemingly

12. See, for example, K Bosselmann, The Principle of Sustainability: Transforming Law and Governance (Ashgate, Hampshire, UK 2008).

13. 2009 JDR 1030 (CC).

14. The concept of 'environmental governance' is used here in its broadest possible sense, see LJ Kotzé, 'Environmental Governance' in AR Paterson and LJ Kotzé Environmental Compliance and Enforcement in South Africa: Legal Perspectives (Juta, Cape Town 2009) 107-08.

15. [2008] JOL 21829 (W).

16. (489/08) [2009] ZASCA 20.

17. R Keightley, 'The Right to Water: What Can We Learn from Mazibuko?', unpublished paper presented during the seminar: 'Water Resources under Threat: Rights and Remedies', held at the Mandela Institute, WITS School of Law, Johannesburg, 27 October 2009: Copy on file with the author.

18. See, Keightley ibid, and P De Vos, Constitutionally Speaking: Water Is Life (but Life Is Cheap) (13 October 2009) available at <http://constitutionallyspeaking.co.za/water-is-life-butlife-is-cheap/>.

19. Keightley (n 17), for example, points to a ' $\ldots$ missed opportunity by the Constitutional Court to give real effect to social and economic rights and social justice'.

20. Keightley (n 17). 
has done in the present instance, this article makes an explicit attempt to explain why, taking a long-term view, the Constitutional Court's judgment might be both positive from an ecological point of view and instructive in understanding the role of socio-economic rights in achieving sustainability. The article also makes a case for the possibility of employing the socio-economic right of access to water in the South African Constitution as a supplementary measure to the environmental right in any future efforts to address the effects of climate change on water resources.

By way of context, the investigation commences with a brief exposition of the state of water resources and water services in South Africa, whereafter the article surveys the impact of climate change in these areas. This contextual part is concluded with a brief reflection on the socio-economic conditions of South Africa's poor with specific reference to the residents of the Phiri township as a case in point. The article then proceeds to briefly analyse the constitutional and statutory provisions related to environmental protection (section 24) and then those regulating socio-economic rights generally, and then specifically, access to water (section 27). The Constitutional Court decision in Mazibuko is then analysed, ${ }^{21}$ and the article concludes with some critical observations and recommendations regarding the role of socio-economic rights in South Africa's efforts to achieve sustainability.

\section{CONTEXTUAL BACKGROUND}

\subsection{Water resources and water service provision}

While South Africa may be rich in minerals, the same cannot be said of water resources. In 2004 the government reflected on this scarcity as follows:

South Africa is located in a predominantly semi-arid part of the world. The climate varies from desert and semi-desert in the west to sub-humid along the eastern coastal area, with an average rainfall for the country of about $450 \mathrm{~mm}$ per year $(\mathrm{mm} / \mathrm{a})$, well below the world average of about $860 \mathrm{~mm} / \mathrm{a}$, while evaporation is comparatively high. As a result, South Africa's water resources are, in global terms, scarce and extremely limited ... Groundwater plays a pivotal role in especially rural water supplies. Because of the predominantly hard rock nature of the South African geology, only about 20 per cent of groundwater occurs in major aquifer systems that could be utilised on a large scale ... To aggravate the situation, most urban and industrial development, as well as some dense rural settlements, have been established in locations remote from large watercourses, dictated either by the occurrence of mineral riches or influenced by the political dispensation of the past. As a result, in several river basins the requirement for water already far exceeds its natural availability.... ${ }^{22}$

Apart from painting a fairly grim picture of the availability (or lack) of water resources in South Africa, the estimation above also clearly indicates the inadequate distribution of water due to industrial activities and past racially discriminatory laws.

21. Owing to limitations of space, this article does not discuss the High Court and Supreme Court of Appeal decisions but focuses on the Constitutional Court's findings, which reflect the final legal position.

22. Department of Water Affairs and Forestry, National Water Resource Strategy (September 2004) published in GN 65 Government Gazette 27199 of 28 January 2005; also available at <http://www.dwaf.gov.za/Documents/Policies/NWRS/Default.htm>. 
In addition, water quality is being severely affected by pollution, especially as a result of mining activities and improper waste management practices generally. ${ }^{23}$ Water is an extremely scarce resource in South Africa and the country, which is already classified as 'water-stressed', ${ }^{24}$ faces a not too distant reality where water demand will surpass the supply of the resource. ${ }^{25}$

South Africa's 'water problem', to borrow a term from Thompson, ${ }^{26}$ is exacerbated by increased demands not only from industry but also from the domestic sector. Population growth and urbanization are only two of the factors that increase the demand for the domestic use of water for personal hygiene and health, to support life, and to grow food. ${ }^{27}$ Unfortunately, South Africa is lagging behind in providing equitable, sustainable and sufficient access to water for domestic use, especially with respect to the most marginalized sectors of society. One of the most defining characteristics of South African society remains the deep divide between the rich and the poor, and while a small, privileged minority has sufficient access to water, the majority of the population, including the poor, unemployed and generally marginalized sectors of the population have no or insufficient access to water. ${ }^{28}$ King, Maree and Muir ${ }^{29}$ point out in this respect that South Africa's Gini co-efficient (which is used to measure income inequality in an economy) is one of the worst in the world; a fact which will necessitate '... government interventions through demand or supply side management ... to address the gaps in service delivery and access to water ... while at the same time being mindful of the increasing poverty gap' and, one might add, the deteriorating environmental conditions.

In 1997, soon after the demise of apartheid, the government stated that: '[T]he loudest cry in South Africa is still for safe, clean and accessible drinking water and sanitation services'. ${ }^{30}$ Without access to sufficient water, people and indeed communities become less resilient, are increasingly subject to grave environmental injustices, and become more exposed to phenomena such as climate change, which, as is pointed out below, will significantly impact on water resources and the manner in which water is provided to people inter alia for domestic use. I have argued elsewhere that ensuring and facilitating equitable and sufficient access to water may very well become, or has already become, one of the most crucial challenges in post-apartheid South Africa. ${ }^{31}$ While this in itself is a daunting task, unfortunately it is also a challenge that undoubtedly will be exacerbated by the deleterious effects of climate change.

23. See, for example, MA Kidd, Environmental Law (Juta, Cape Town 2008) 64, 148-53, and Thompson (n 1).

24. Thompson (n 1) indicates that ' $[\mathrm{O}] \mathrm{f}$ the 149 countries in the world for which data is available, South Africa was at the end of the $20^{\text {th }}$ century the $26^{\text {th }}$ most stressed in terms of water availability' 7 .

25. Department of Environmental Affairs and Tourism, State of Environment Report (2006) Chapter 6.2 et seq; NA King, G Maree and A Muir 'Freshwater Systems' in HA Strydom and ND King (eds), Fuggle and Rabie's Environmental Management in South Africa ( $2^{\text {nd }}$ edn Juta, Cape Town 2009) 435; and JA Day, 'Rivers and Wetlands' in the same volume, 842-44.

26. See generally Thompson (n 1) 7 et seq.

27. King, Maree and Muir (n 25) 435.

28. Thompson (n 1) 9 .

29. King, Maree and Muir (n 25) 439. See also Liebenberg and Goldblatt (n 8) at 336.

30. National Water Policy for South Africa: White Paper, 1997 at para 4.1.2.

31. LJ Kotzé, 'Access to Water in South Africa: Constitutional Perspectives from a Developing Country’ (2009) 29(97) Finnish Environmental Law Review 72. 


\subsection{The impact of climate change}

As part of sub-Saharan Africa, South Africa is one of the countries expected to experience the greatest negative effects of climate change while possessing the least capacity and resources to adapt to these impacts. ${ }^{32}$ More specifically, official reports and surveys estimate that climate change will have a significant impact on water resources in South Africa. The most recent State of Environment Report (SoER) found, for instance, that climate change will alter hydrological systems and reduce the availability of water; generally there will be a decrease of between 10 and 15 per cent in annual rainfall and while some areas will become drier, others will see more frequent and severe floods; a significant reduction of run-off water and stream-flow reduction of up to 10 per cent is envisaged, even as soon as 2015; reduced natural yields and reliability will occur; and, ultimately, a decrease in the quantity and quality of water will increase the cost of water. ${ }^{33}$ Notably, climate change will not only have a serious impact on South Africa's natural resources, but it will also affect the country's efforts to improve the socio-economic conditions of its inhabitants, including the provision of water. Climate change will especially have a very direct adverse effect on the poor inhabitants of South Africa, and there is currently little doubt that:

Climate change is the wild card in South Africa's efforts to maintain a functioning environment and the ecosystem services it provides for all human endeavour and particularly in the fight against poverty. ${ }^{34}$

In short, the already dry country will become drier and the water supply less predictable, which will cumulatively affect the ability of government effectively to realize the constitutionally guaranteed socio-economic entitlements of people. As Tandon puts it: '[C]limate change compounds the complexity and costs of ensuring water security, particularly in countries and regions with difficult "hydrologic legacies". 35 This add-on effect of external pressures resulting from climate change on a socio-economic system already under severe pressure will in all likelihood be enormous. ${ }^{36}$

Inaction or short-sighted solutions are unsustainable and will only erode some of the developmental gains achieved since the demise of apartheid. ${ }^{37}$ Any decision regarding water that is now made, be it by a court, the legislature or by government,

32. AB Rumsey and ND King, 'Climate Change: Adaptation, and Mitigation; Threats and Opportunities' in Strydom and King (eds) (n 25) 1048.

33. Department of Environmental Affairs and Tourism, State of Environment Report (2006) Chapter 6.2.4. See also the South African National Climate Change Response Strategy (September 2004) para 2.2 at <http://unfccc.int/files/meetings/seminar/application/pdf/ sem_sup3_south_africa.pdf> and RE Schulze (ed), Climate Change and Water Resources in Southern Africa: Studies on Scenarios, Impacts, Vulnerabilities and Adaptation, WRC Report no 1430/1/05 (Water Research Commission, 2005).

34. Rumsey and King (n 32) 1048.

35. N Tandon, 'Biopolitics, Climate Change and Water Security: Impact, Vulnerability and Adaptation Issues for Women' (2007) Agenda 73 at 4.

36. See J Turpie et al., Economic Impacts of Climate Change in South Africa: a Preliminary Analysis of Unmitigated Damage Costs (Southern Waters Ecological Research and Consulting and Energy and Development Research Centre, University of Cape Town, February 2002) 2 and 6, and P Mukheibir, 'Possible Climate Change Impacts on Large Hydroelectricity Schemes in Southern Africa' (2007) 18(1) Journal of Energy in Southern Africa 4-9.

37. Rumsey and King (n 32) 1076-77. Tandon (n 35) 12. 
will undoubtedly have severe ramifications for present and future generations. As far as water resource protection and the provision of access to water are concerned, what will be critical is a long-term approach which recognizes the finite limits of South Africa's water resources; an approach which would allow people as much access to water resources as would be necessary to sustain livelihoods, while simultaneously protecting these resources for future generations; and, ultimately, an approach which would factor in the increased pressures of climate change. ${ }^{38}$ Whether the Constitutional Court in Mazibuko was either short- or far-sighted (unsustainable versus sustainable) in its interpretation of section 27 is a matter to which I will return below.

\subsection{Phiri's poor}

Despite enormous progress in the past 15 years of democratic rule, poverty arguably remains the scourge that taints the country's endeavours to realize some of the most basic founding constitutional values of the South African state. These values include human dignity, ${ }^{39}$ the achievement of equality, and the advancement of human rights and freedoms. ${ }^{40}$ No doubt much of the blame for the current situation can be laid at the door of the previous apartheid regime. Unfortunately, however, where water and related socio-economic services are concerned, issues such as the scarcity and maldistribution of water, water pollution, structural ecosystem damage and insufficient sanitation have been exacerbated by current neoliberal government policies. ${ }^{41}$ Unequal distribution patterns therefore remain, and these seem still to be influenced by class, race and gender considerations. ${ }^{42}$

Apart from inequalities with respect to access to water resources, the country has to deal with numerous other challenges such as HIV/AIDS, unemployment, environmental injustices, lack of housing and, generally, immense socio-economic decay. ${ }^{43}$ The residents of Phiri township (situated in Soweto, Johannesburg), ${ }^{44}$ some of whom are also the applicants in Mazibuko $v$ City of Johannesburg, are no exception

38. South African National Climate Change Response Strategy (n 33).

39. There is a close and perhaps obvious correlation between human dignity and socioeconomic entitlements. See S Liebenberg, 'The Value of Human Dignity in Interpreting Socio-economic Rights' (2005) 21 SAJHR 1-31.

40. Section 1 of the Constitution. See P Bond (n 11).

41. P Bond and D Hallowes, 'The Environment of Apartheid-capitalism' in Bond (n 11) 35; Magaziner (n 4) 523; De Vos (n 18); V Shiva, Water Wars: Privatization Pollution and Profit (South End Press, Cambridge, MA 2002); M Finger and J Allouche, Water Privatisation: Trans-national Corporations and the Re-regulation of the Water Industry (Spon Press, London 2001); MB Likosky (ed), Privatising Development: Transnational Law, Infrastructure and Human Rights (Martinus Nijhoff Publishers, Netherlands 2005).

42. Bond and Hallowes, ibid 35; Liebenberg and Goldblatt (n 8) 334-35.

43. See J Martinez-Alier, The Environmentalism of the Poor: a Study of Ecological Conflicts and Valuation (Edward Elgar, Cheltenham 2002); and P Dasgupta, 'Poverty and the Environment: Is There a Trade-off?' in L Campiglio et al. (eds), The Environment after Rio: International Law and Economics (Graham and Trotman/Martinus Nijhoff, International Environmental Law and Policy Series 1994).

44. Soweto (South Western Townships) was created under the previous apartheid regime as an exclusively 'black residential area' in terms of the regime's policies of segregation and racial discrimination. 
and serve as a case in point. ${ }^{45}$ The socio-economic conditions prevailing in the township mirror those in other poor areas in South Africa, and its residents have been described as 'poor, uneducated, unemployed and ... ravaged by HIV/AIDS' ${ }^{46}$ Each water account holder in the township has more than one household on his/her stand and more than 16 people reside in most of these households. ${ }^{47}$ Those residents who are employed earn approximately ZAR 1100 per household per month. ${ }^{48}$ The majority of the residents depend on government-provided old age pensions and/or child support grants. Judging from these statistics, it is safe to surmise that the prevailing socio-economic conditions in the township are extremely dire. ${ }^{49}$

Adding fuel to the flames, it is envisaged that the impact of climate change on communities such as Phiri will be severe and that these impacts will exacerbate the already unacceptable socio-economic conditions. Drawing from the United Nations Intergovernmental Panel on Climate Change (IPCC) 'Climate Change 2007: Impacts, Adaptation, and Vulnerability' Working Group II Contribution to the Intergovernmental Panel on Climate Change, Fourth Assessment Report, Tandon ${ }^{50}$ links climate change impacts on water resources and the poor as follows:

Poor communities are especially vulnerable, in particular those concentrated in high-risk areas. They tend to have more limited adaptive capacities and are more dependent on climate sensitive resources, such as local water and food supplies. ${ }^{51}$

This underlines the inferences in sections 2.1 and 2.2 above: the poor, such as the residents of Phiri, will suffer most from the impact of climate change on water resources, which will have a very direct effect on the availability of water resources and the equal and sufficient distribution of water to satisfy basic socio-economic needs.

\section{THE LAW}

South Africa has a relatively modern environmental law and governance framework, ${ }^{52}$ which has been conceptualized and designed around the environmental right in the Constitution and draws its legitimacy, rationale and currency from this

45. This article employs the Phiri residents as a representative example of a much broader issue. 46. Mazibuko and others $v$ City of Johannesburg and others (Centre on Housing Rights and Evictions as amicus curiae) [2008] JOL 21829 (W) at para 5. See also Magaziner (n 4) at $521-22$.

47. Mazibuko and others $v$ City of Johannesburg and others (Centre on Housing Rights and Evictions as amicus curiae) [2008] JOL 21829 (W) para 166.

48. Approximately US\$149 in March 2010.

49. See the analysis of the High Court judgment and its reference to Phiri's poor: jammergevalle, an Afrikaans word which, loosely translated, means 'pity cases', denoting a sense of compassion. See further L Jansen van Rensburg, 'The Right of Access to Adequate Water [Discussion of Mazibuko v the City of Johannesburg Case no 13865/06]' (2008) 3 Stellenbosch Law Review 415.

50. Tandon (n 35) at 6.

51. See C Vogel and P Reid, 'Vulnerability, Adaptive Capacity, Coping and Adaptation: a Conceptual Framework' in Schulze (n 33) 351-58.

52. For an overview of South Africa's environmental law regime, see for instance LJ Kotzé et al., South African Environmental Law through the Cases (LexisNexis Butterworths, 2008); Kidd (n 23); Paterson and Kotzé (n 14); and LJ Kotzé and AR Paterson, 'South Africa' in LJ Kotzé and AR Paterson (eds), The Role of the Judiciary in Environmental Governance: Comparative Perspectives (Kluwer Law, Netherlands 2009) 557-601. 
right. In addition to the environmental right, the Constitution also provides a host of procedural and other substantive rights that may be used to bolster environmental protection. ${ }^{53}$ The Constitution further sets out certain socio-economic rights, including the rights of access to adequate housing, social security and assistance, education - and the subject matter of this enquiry - the right of access to sufficient water. These rights are, in most instances, directly or indirectly related to environmental concerns. ${ }^{54}$ As is illustrated in sections 4 and 5 below, while water-resource protection was an underlying theme in Mazibuko, neither the environmental right nor water-resource protection legislation featured explicitly in the case. The emphasis was rather on section 27 and the statutory provisions related to water services provision. However, water resource protection was in my opinion a salient feature of Mazibuko, and the provisions related to water resources protection therefore warrant a brief investigation in section 3.1 below. Section 3.2 focuses on socio-economic rights in South Africa generally and then the constitutional and statutory provisions that were scrutinized in Mazibuko. ${ }^{55}$

\subsection{Environmental right and water resource protection}

Section 24 of the Constitution provides:

\section{Everyone has the right -}

(a) to an environment that is not harmful to their health or well-being; and

(b) to have the environment protected, for the benefit of present and future generations, through reasonable legislative and other measures that -

(i) prevent pollution and ecological degradation;

(ii) promote conservation; and

(iii) secure ecologically sustainable development and use of natural resources while promoting justifiable economic and social development. ${ }^{56}$

This is the only right in the Bill of Rights that explicitly provides for 'sustainability'. It has as its primary objective the protection of the health and well-being of people through legislative and other measures which, at a minimum, must protect the environment, prevent pollution and ecological degradation, and promote conservation. ${ }^{57}$ It is unashamedly anthropocentric in nature and guarantees ecological sustainable development only in so far as ecological sustainability does not impede justifiable

53. These include the right to equality (section 9), the right to human dignity (section 10), the right to life (section 11), the right of access to information (section 32), the right to administrative justice (section 33), the right to have access to courts (section 33), and the enforcement of rights clause (section 38). See further, Feris and Tladi (n 10) 250-51.

54. See sections 26, 27, 28 and 29 of the Constitution. For a general discussion of socio-economic rights in South Africa, also see Brand and Heyns (n 7).

55. Note that, apart from some incidental provisions in the National Environmental Management: Air Quality Act 39 of 2004, South African law contains no express provisions on climate change.

56. See L Feris, 'Environmental Rights and Locus Standi' in Paterson and Kotzé (n 14) 129-51.

57. See for example: Kidd (n 23); L Feris and D Tladi, 'Environmental Rights' in Brand and Heyns (n 7) 249-64; Kotzé and Paterson (n 52) 560-62; Du Plessis (n 9) 15-98. 
economic and social (human) development. In this sense it is ambitious, because it seeks to ensure some level of environmental protection, while simultaneously allowing the possibility for socio-economic development, provided the latter can be justified. ${ }^{58}$ In a deliberate effort to refrain from delving too deeply into the South African environmental rights discourse, it suffices to say for the purpose of this enquiry that the environmental right will and does influence government actions, legislation, policies and in fact, all other measures which can be employed to realize the objectives of the right. ${ }^{59}$ The environmental right should therefore, at least on paper, also influence government's actions with respect to the governance or protection of water resources and thus have a direct bearing on efforts to provide people with sufficient access to water as per section 27 of the Constitution. In this sense the environmental right can be employed to safeguard the ecological aspects of water resources, ie protection of the resource, ${ }^{60}$ while allowing some form of resource exploitation for socioeconomic purposes, among others, but only in so far as these socio-economic demands are 'justifiable'. Given the anthropocentric nature of the South African environmental right and considering the internal 'limitations' ${ }^{\prime 61}$ on the ecological objectives of the right, which allow for a limited degree of socio-economic development, one can conclude that the right provides the constitutional justification for any intervention that would be required to sustainably use water resources. ${ }^{62}$ Any such intervention must take a balanced view of the dictates of sustainability, ie it would be important to protect the resource but only to the extent that resources protection does not unjustifiably deny people access to sufficient water. ${ }^{63}$ Whether or not the Constitutional Court in Mazibuko followed this line of argument in reaching its conclusion is investigated below.

Protection of water resources in terms of section 24, notably, is accomplished by means of the National Water Act 36 of 1998 (NWA). ${ }^{64}$ The purpose of this law is, inter alia, to:

2. Ensure that the nation's water resources are protected, used, developed, conserved, managed and controlled in ways which take into account amongst other factors:

(a) meeting the basic human needs of present and future generations;

(b) promoting equitable access to water;

58. No court has thus far attributed content to the right. LJ Kotzé, 'The Judiciary, the Environmental Right and the Quest for Sustainability in South Africa: a Critical Reflection' (2007) 16(3) Review of European Community and International Environmental Law 298-311; Kotzé and Paterson (n 52) 572-79.

59. This was reiterated by the Supreme Court of Appeal in Director: Mineral Development, Gauteng Region, and Another $v$ Save the Vaal Environment and Others 19992 SA 709 (SCA) at paras $719 \mathrm{C}-719 \mathrm{D}$.

60. Water resources protection in South Africa is primarily accomplished in terms of the National Water Act 36 of 1998 (NWA) and its accompanying regulations.

61. These 'limitations' must be read with the general limitation clause in sections 36(1) and (2) of the Constitution.

62. The Preamble to the NWA, states, for example, '... the ultimate aim of water resource management is to achieve the sustainable use of water for the benefit of all users'. See Thompson (n 1) 356-61.

63. The NWA seems to attempt this by means of the 'reserve' that is established in sections $16-18$ of the Act.

64. See Kidd (n 23) 64-88, and Thompson (n 1). 
(c) redressing the results of past racial and gender discrimination;

(d) promoting the efficient, sustainable and beneficial use of water in the public interest;

(e) facilitating social and economic development;

(f) providing for growing demand for water use;

(g) protecting aquatic and associated ecosystems and their biological diversity;

(h) reducing and preventing pollution and degradation of water resources;

(i) meeting international obligations; ...

(k) managing floods and droughts. ${ }^{65}$

It is evident from the provisions above that the NWA is not meant only to protect water resources. It seems that the approach of this law seeks to protect the resource while also attempting to satisfy the socio-economic needs of people, and in this sense it neatly coincides with the dictates of the environmental right.

While the provisions of the NWA and section 24 were not scrutinized by the Court in Mazibuko, it is important to note here that their mere existence is evidence of the importance that the South African legal system places on the proper governance of water resources and the protection of the ecological integrity of water resources with a view to providing present and future generations with sufficient opportunities to enjoy, and more importantly, to use this life-sustaining resource. ${ }^{66}$

\subsection{Socio-economic rights in South Africa}

\subsubsection{General observations on the prevailing discourse}

The motivation behind the inclusion of socio-economic rights in the South African Constitution is mainly attributable to the country's racially discriminatory past, which brought about great suffering, inequalities and deprivation in large sectors of society. ${ }^{67}$ In this sense, the provision of these socio-economic rights aims to correct certain wrongs by being transformative; ie these rights, together with various other constitutional provisions, require '... collective power to be used to advance ideals of freedom, equality, dignity and social justice'. ${ }^{68}$ This role is facilitated in the context of a transformative Constitution which '... aims to facilitate a fundamental transformation in the unjust political, economic and social conditions inherited from our colonial and apartheid past, and to create a new society based on social justice, democracy and human rights'. ${ }^{69}$ Undoubtedly:

\section{Section 2 .}

66. Such a view also coincides with and is supported by the definition of 'water reserve' in section 1 of the NWA.

67. See Liebenberg (n 8) 33-3-33-5 and DM Davis, 'Adjudicating the Socio-economic Rights in the South African Constitution: Towards “Deference Lite"?' (2006) 22 SAJHR 301-27 at 302-03. 68. D Brand (n 7) in Brand and Heyns (n 7) 1. See also L Jansen van Rensburg 'Interpreting Socio-economic Rights - Transforming South African Society?' (2003) 6(2) PER 1/15-13/15; S Liebenberg, 'Needs, Rights and Transformation: Adjudicating Social Rights in South Africa' (2005) 6(4) ESR Review 3-7; P De Vos, 'Grootboom, the Right of Access to Housing and Substantive Equality as Contextual Fairness' (2001) 17 SAJHR 258-76 at 260-63. On the transformative role of socio-economic rights and the constitutional right to equality (section 9), see Liebenberg and Goldblatt (n 8) 335-61.

69. Liebenberg and Goldblatt (n 8) at 338. 
The dismantling of systemic forms of disadvantage and subordination in our post-apartheid society is central to the Constitution's transformative vision. This requires redressing pervasive forms of status subordination ... as well as systemic patterns of social and economic disadvantage. ${ }^{70}$

Being transformative, however, is not the only function of such socio-economic rights; they also act as a guarantee with respect to the availability of those conditions and dimensions that influence human welfare. This is so because they acknowledge that '... without food, water, shelter, health care, education and social security, human beings cannot survive, live with dignity or develop to their full potential'. ${ }^{71}$ Liebenberg ${ }^{72}$ elegantly captures the meaning, role and importance of socio-economic rights in South Africa as follows:

Socio-economic rights are not valued as commodities, but because of what they enable human beings to do and to be. If basic subsistence needs are not met, humans face severe threats to life and health. But, in addition, such deprivation impedes the development of a whole range of human capabilities, including the ability to fulfil life plans and participate effectively in political, economic and social life. It also deprives society of the contributions of all its members. Thus both the individual and society are impoverished by our collective failure to ensure living conditions worthy of the dignity of people as both individual and social beings.

One can distinguish three categories of socio-economic rights in the Constitution, namely qualified rights, ${ }^{73}$ basic rights, ${ }^{74}$ and rights formulated to impose prohibitions against certain state and private party conduct. ${ }^{75}$ The right of access to water in section 27 is an example of a qualified right, since government must only progressively provide 'access' to water through reasonable legislative and other measures within its available resources. In other words, the state does not literally have to provide people with water, only access to water; the provision of such access must be facilitated by means, for example, of legislation and policies. Realization need not be immediate, only progressive or gradual, and only insofar as the public purse allows it. Apart from these 'limited' entitlements and concomitant obligations stemming from qualified socio-economic rights, the state must additionally, by virtue of section 7 of the Constitution, '... respect, protect, promote and fulfil the rights in the Bill of Rights'. The state will therefore be precluded from law or conduct that infringes upon the enjoyment of certain rights (the duty to respect) ${ }^{76}$ it must take measures to protect vulnerable people from violations of their rights (the duty to protect); and it must fulfil socio-economic rights, for example by providing people access to a socio-economic entitlement where they currently lack such access (duty to promote and fulfil). ${ }^{77}$

70. Liebenberg and Goldblatt (n 8); S Liebenberg, 'Needs, Rights and Transformation: Adjudicating Social Rights' (2006) 1 Stell LR 5-36.

71. Liebenberg (n 8) 33-1 and Davis (n 67) 302.

72. Liebenberg (n 39) at 3.

73. Sections 26(1) and 27(1).

74. Sections 28(1)(c), 29(1)(a) and 35(2)(e).

75. Sections 26(3) and 27(3). See Liebenberg (n 8) 33-5-33-6; Brand (n 7) 3-4; and L Stewart, 'Interpreting and Limiting the Basic Socio-economic Rights of Children in Cases Where They Overlap with the Socio-economic Rights of Others' (2008) 24 SAJHR 472-94 at 473.

76. In the context of section 27 the state will not respect this right if, for example, it displaces existing access to water, for instance by the installation of a pre-payment meter - discussed below.

77. Liebenberg (n 8) 33-6-33-7; Stewart (n 75) at 475. 


\subsubsection{Right of access to water $^{78}$}

The right of access to water is an important part of the socio-economic rights framework and discourse discussed earlier. There are obvious reasons for elevating obligations related to the provision of access to water to the constitutional level. ${ }^{79}$ The Constitutional Court in Mazibuko accurately captured these as follows:

Cultures in all parts of the world acknowledge the importance of water. Water is life. Without it, nothing organic grows. Human beings need water to drink, to cook, to wash and to grow our food. Without it, we will die. It is not surprising then that our Constitution entrenches the right of access to water. ${ }^{80}$

A plain reading of section 27 warrants a few general observations: (a) the right can be classified as a socio-economic right; ${ }^{81}$ (b) literally everyone in South Africa is entitled to the right; ${ }^{82}$ (c) the right is internally qualified or limited in that it only extends to a right to access to water and not to water per se, ${ }^{83}$ (d) the right is further delineated in the sense that access relates to sufficient water and not undetermined and unqualified access; (e) the concept of 'sufficiency' is not explained in any of the applicable laws and it is therefore unclear whether it relates to water both of a sufficient quality and/or quantity; (f) the grouping of the right of access to water with other entitlements, such as health care services, food and social security, clearly suggests that access to water is recognized as one of the basic 'entitlements to material conditions for human welfare', ${ }^{84}$ and as such it depends on, is interlinked with, and is conditional on the effective realization of various other socio-economic rights and constitutional objectives and ideals ${ }^{85}(\mathrm{~g})$ because it is a socio-economic right, there is a duty on the government to provide access to sufficient water; ${ }^{86}(\mathrm{~h})$ this duty is limited in that the government must only progressively realize ${ }^{87}$ the right of access to water by way of reasonable legislative and other measures within its available resources ${ }^{88}$-immediate fulfilment is therefore not required and progressive fulfilment further is conditional on resources being available; and (i) the right does not explicitly provide for access to basic sanitation and further seems to be linked, as a plain reading suggests, with the right of access to sufficient food.

78. See Kotzé (n 31) 70-106 and A Kok and M Langford, 'The Right to Water' in Brand and Heyns (n 7) 191-208.

79. The significance of elevating obligations and entitlements to constitutional level protection is evident from sections 7 and 8 of the Bill of Rights.

80. Mazibuko v City of Johannesburg 2009 JDR 1030 (CC) at para 1, as per O'Regan J.

81. See D Brand (n 7) in Brand and Heyns (n 7) 1-56; M Seleonane and B Pityana, SocioEconomic Rights in the South African Constitution: Theory and Practice (HSRC Publishers, Pretoria 2001); and P Jones and K Stokke, Democratising Development: the Politics of Socio-economic Rights in South Africa (Martinus Nijhoff Publishers, Netherlands 2005).

82. This also corresponds with the universal character usually associated with fundamental rights.

83. Liebenberg (n 8) 33-22.

84. Brand (n 7 ) 3 and Liebenberg (n 8) 33-1.

85. This does not necessarily imply that there is an existing hierarchical order in terms of socio-economic rights.

86. Section 7(1) of the Constitution places additional duties on government to respect, protect and promote the full enjoyment of the right.

87. Liebenberg (n 8) 33-41-33-44.

88. Liebenberg (n 8) 33-44-33-47. 
The Water Services Act 108 of 1997 (WSA) was promulgated as part of the 'reasonable legislative and other measures' envisaged by section $27 .{ }^{89}$ The Act therefore is the principal legislative mechanism in terms of which government must give effect to its duties as set out in section 27 of the Constitution. The Act aims to provide inter alia for "the right of access to basic water supply and the right to basic sanitation necessary to secure sufficient water and an environment not harmful to human health or well-being'; $;{ }^{0}$ and 'the setting of national standards and norms and standards for tariffs in respect of water services' (the social purpose of water). ${ }^{91}$ The Act therefore aims concomitantly to promote effective water resource management and conservation (the ecological purpose of water). ${ }^{92}$

The WSA defines 'basic water supply' as 'the prescribed minimum standard of water supply services necessary for the reliable supply of a sufficient quantity and quality of water to households, including informal households, to support life and personal hygiene'.$^{93}$ The minimum standard for basic water supply is 25 litres of potable water per person per day or 6 kilolitres per household per month (the latter being the quantity that was supplied by the City of Johannesburg to households in Phiri). ${ }^{94}$ This water is to be provided free of charge, in line with the government's policy on free basic water supply, namely the Free Basic Water Programme, 2001. Currently, the government provides water to 36.5 million out of an estimated 48.5 million people, ${ }^{95}$ but there nevertheless remain an estimated 12 to 14 million people without any access to sufficient water. Chapter 3 of the Act establishes water services authorities that include municipalities (local government), ${ }^{96}$ each of which has a duty to "consumers or potential consumers in its area of jurisdiction to progressively ensure efficient, affordable, economical and sustainable access to water services' ${ }^{97}$ In addition to these authorities, water services providers ${ }^{98}$ and intermediaries ${ }^{99}$ are established. These bodies have the responsibility and authority to provide water services, and in the case of Mazibuko, are those same authorities whose policies, plans and actions were challenged by the applicants.

The analysis above suggests that the legal regime with respect to water resource governance in South Africa is broadly premised on a two-pronged approach which,

89. Its preamble recognizes 'the rights of access to basic water supply and basic sanitation necessary to ensure sufficient water and an environment not harmful to health or wellbeing'; and further acknowledges 'a duty on all spheres of Government to ensure that water supply services and sanitation services are provided in a manner which is efficient, equitable and sustainable'.

90. Section 2(a).

91. Section 2(b).

92. Section $2(\mathrm{j})$.

93. Section 1 defines 'basic sanitation and Regulation 2 of GN R 509, Government Gazette of 8 June 2001 promulgated under the WSA determines the minimum standard for basic sanitation services.

94. See Regulation 3 in GN R 509, ibid.

95. See Department of Water Affairs and Forestry: <http://www.dwaf.gov.za/FreeBasicWater/> and Kidd (n 23) 84.

96. Under s1 of the WSA and the Local Government Transition Act 209 of 1993.

97. Section 11(1). Municipalities in South Africa are severely under-resourced and undercapacitated and experience increased challenges in providing basic municipal services. See Du Plessis (n 9).

98. Chapter 4 of the WSA. 'Water services provider' is defined in s1 of the WSA

99. Chapter 5 of the WSA. 'Water services intermediary' is defined in s1 of the WSA. 
ideally, must provide for comprehensive resource protection on the one hand and resource use and exploitation on the other, with a view to enabling justifiable and sustainable socio-economic use of a scarce environmental resource.

\section{MAZIBUKO V CITY OF JOHANNESBURG}

\subsection{The plight of the poor}

The Mazibuko saga commenced in 2004 when the City of Johannesburg (local government) decided to install prepayment water meters in the township of Phiri. In terms of the City's Free Basic Water policy, residents were entitled to 6000 litres of free water per household per month for domestic use. When this quantity was exceeded, the water supply would automatically be discontinued by the meter and could be reactivated only by purchasing further credit. This venture by the government had a duel objective: (a) to recover enormous outstanding debts related to unpaid water services by the Phiri residents, and (b) to save water by upgrading service provision infrastructure and discouraging wasteful water practices (or, as some put it, to 'reduce demand'). ${ }^{100}$ That these debts and water wastage were of great concern to the government is evident from the following facts that were tendered in the Constitutional Court:

Johannesburg Water [a water services company wholly owned by the City] estimated that between one quarter and one third of all water it purchased was distributed to Soweto, while only one percent of revenue was generated from Soweto. One of the reasons for the shortfall in revenue was the fact that many residents did not pay the deemed consumption charges. Johannesburg Water estimated that $75 \%$ of all water pumped into Soweto was unaccounted for. The water losses in Soweto far exceeded losses in other areas ... ${ }^{101}$

In an effort to encourage residents to opt for the prepayment meters, the government undertook to write off all outstanding debts and arrears with respect to past services if residents chose to install the meters. By 2004 all but a few residents had accepted the prepayment meters, and a customer satisfaction survey conducted in 2006 suggested that approximately 80 per cent of customers were satisfied with the new prepayment system. ${ }^{102}$ The applicant in the High Court and Constitutional Court cases, Lindiwe Mazibuko, was one of the residents who wished not to have the prepayment meter installed. Together with several other Phiri residents, she challenged various aspects of the city's water provision policy and actions to implement the policy. ${ }^{103}$

The two issues in the High Court application were (a) whether the city's Free Basic Water policy and the quantity of 6000 litres of free water per household per month were in compliance with section 27 of the Constitution, and (b) whether the

100. P Bond and J Dugard, 'The Case of Johannesburg Water: What Really Happened at the Pre-paid "Parish Pump" (2008) 12(1) Law Democracy and Development at 9.

101. Mazibuko v City of Johannesburg at para 12. The City's strategy to change patterns of water usage in Soweto is known as Operation Gcin'amanzi (to save water). See Mazibuko v City of Johannesburg at para 13 for details and L Holtzhausen, 'Full-scale Rollout of Operation Gcin'amanzi' WASE Africa (September 2004) 16-19.

102. Thirty-five refusals, to be exact: Mazibuko $v$ City of Johannesburg at paras 17-18.

103. It is trite that the party claiming the violation of a socio-economic right bears the burden of proving such infringement. In casu, this onus of proof rested on Mrs Mazibuko and the other claimants. See also Liebenberg (n 8) 33-53-33-54. 
installation of the prepayment meters was lawful. ${ }^{104}$ The High Court handed down judgment in favour of the applicants on 30 April 2008. It held, inter alia, that the city's by-laws did not provide for the installation of the meters and that the installation was accordingly unlawful; because the meters halted the water supply once 6000 litres were exceeded, the meters resulted in unlawful and unreasonable discontinuation of water supply; the procedure to install the meters was unlawful and unfair; and the Free Basic Water policy of the city was irrational and unreasonable. Significantly, the Court held that the city should furnish the applicants and all similarly placed residents of Phiri with a free basic water supply of 50 litres per person per day. ${ }^{105}$

Not surprisingly, this judgment was appealed by the city to the Supreme Court of Appeal. ${ }^{106}$ On 25 March 2009 the Court unanimously held that the city's water services policy had incorrectly been formulated on a misconception by the City that it did not have to provide the minimum quantity of water in terms of its by-laws, and that for this reason the policy had to be set aside. The Court further found that the residents of Phiri could directly rely on their section 27 right of access to water (the so-called 'direct reliance rule') and were therefore not obliged to base their claim on the provisions of legislative and other measures (for example the WSA and its regulations) to give effect to section $27 .{ }^{107}$ The result of such an interpretation is particularly beneficial to claimants since, as Dugard and Liebenberg put it: ${ }^{108}$

... challenges to water policies cannot be based on existing legislation, as this would place a constitutional straitjacket on litigants seeking to challenge the adequacy of existing legal and policy measures which impact on the realisation of socio-economic rights.

The Supreme Court of Appeal also reduced the quantity of water ordered by the High Court to 42 litres per person per day and referred the policy back for redetermination by the city. The Court further confirmed that the city had no lawful authority to install the prepayment meters and that discontinuation of water supply by means of the meters amounted to unlawful discontinuation of water services. As a consequence, it declared the installation of the meters to be unlawful, but suspended the order for two years to enable the city to rectify the situation by means of its by-laws.

In a nutshell, the High Court and the Supreme Court of Appeal judgments clearly favoured Lindiwe Mazibuko and the other poor residents of Phiri. Their right of access to water could, in the view of the two courts, not be denied them by discontinuing the water supply by means of prepayment meters. Moreover, Phiri's residents

104. See Bond and Dugard (n 100) 1-28; Kotzé (n 31) 90-96; and Jansen van Rensburg (n 49) 415-35.

105. For a summary of the findings of the High Court see Mazibuko v City of Johannesburg at paras 25-27. In short, the Court reasoned that it was uncontested that the City had the financial means to increase the free basic water supply; the prepayment meters were installed in predominantly 'black' areas such as Phiri, an act which contravened the constitutional right to equality (section 9) and which also amounted to indirect racial discrimination and discrimination against the poor; the prepayment meters arbitrarily limited water supply; and this limitation placed an unreasonable burden on especially poor black women to fetch water from elsewhere. J Dugard and S Liebenberg, 'Muddying the Waters: the Supreme Court of Appeal's Judgment in the Mazibuko Case' (2009) 10(2) ESR Review 11-16 at 13.

106. See Mazibuko v City of Johannesburg at Para 28 and Kotzé (n 31) 97-100; L Stewart and D Horsten, 'The Role of Sustainability in the Adjudication of the Right to Access to Adequate Water' (2009) 24 SAPL 486-505; Dugard and Liebenberg (n 105) 11-16.

107. City of Johannesburg $v$ Mazibuko at para 13.

108. Dugard and Liebenberg (n 105) at 13-14. 
now had access to almost double the quantity of the free water they had had prior to the litigation (42 litres per person per day as opposed to 25 litres). This was indeed an overwhelming victory for Phiri's poor. On the other hand, the City was clearly the loser in every respect. The practical results of the courts' orders were, for instance, that the City had to supply a significantly increased quantity of free water, ${ }^{109}$ that it had to discontinue the use of prepayment meters and remove those already installed, possibly at a significant cost; that it had to upgrade infrastructure to ensure a constant sustainable supply of water; and that in the absence of prepayment meters it had to continue maintenance and service provision without the guarantee of being reimbursed for the expenses. More importantly, it had to improve and continuously maintain a severely dilapidated water services infrastructure without adequate financial resources to do so, and it had to find the money from somewhere to pay (literally on behalf of its customers) for the use of a scarce environmental resource already under severe strain. In these circumstances, any increased pressure on or disturbance of this resource, caused for example by severe droughts as a result of climate change, would in all likelihood have had a severe impact on the ability of the City to adequately fulfil not only its existing constitutional and legislative obligations, but also those additional obligations recently imposed by the two courts.

Considering the victory of the parties described above, it was rather surprising that they chose to appeal the judgment to the Constitutional Court. The case in the Constitutional Court was an application for leave to appeal against the judgment of the Supreme Court of Appeal, in terms of which the applicants essentially sought the reinstatement of the High Court order. ${ }^{110}$ The applicants did not seek to appeal against the order declaring the prepayment meters unlawful, but only against the two-year suspension of this order. The applicants also argued that the Supreme Court of Appeal erred in determining that the quantity of 42 litres per person per day was adequate and asked the Court in casu to adjust this quantity to 50 litres as per the High Court decision. Finally, they also argued that the Supreme Court should have declared that the City was obliged to provide 50 litres per person per day free of charge to all of the residents of Phiri who could not afford to pay for water.

\subsection{The voice of reason?}

One cannot envy the Constitutional Court the monumentally difficult task it had to perform in adjudicating Mazibuko. Undoubtedly, as Magaziner ${ }^{111}$ puts it: '[T]he temptation to feed the need for socioeconomic reform places heavy burdens on the South African judiciary seeking to delineate the terms of the Bill of Rights'. Certainly, the enforcement of social justice by the courts for the benefit of the poor, vulnerable and marginalized is as difficult as it is highly commendable in a society where deep rifts of injustice and inequality remain. Did the Constitutional Court constructively respond to the plight of Phiri's poor?

In what has been described by some as: '.. a missed opportunity by the Constitutional Court to give real effect to social and economic rights and social justice' ${ }^{112}$ the Constitutional Court, on 8 October 2009, unanimously found against the applicants on

109. The City would probably also have had to supply more water as more residents would likely be attracted to the area increasing pressure on the already strained water services.

110. Mazibuko $v$ City of Johannesburg at para 30.

111. Magaziner (n 4) at 579.

112. Keightley (n 17). 
every issue. It set aside the orders of both the High Court and the Supreme Court of Appeal with the resultant effect that: '[T]he applicants walked away empty-handed, with the Court dismissing every challenge to the City's water policy, and finding that the policy was constitutionally sound in every respect'. ${ }^{113}$ How did the Court come to this surprising and, to some, shocking conclusion? ${ }^{114}$

\subsubsection{Approach to interpretation}

In an attempt to determine what constituted 'sufficient' water, the High Court and Supreme Court of Appeal first and foremost sought to determine the content of the right of access to water under section 27(1)(b). For the High Court this was 50 litres per person per day; a quantity which was subsequently reduced by the Supreme Court of Appeal to 42 litres. This first step of enquiry was followed by a determination on whether there rested an obligation on the government to progressively provide this quantity within its available resources. ${ }^{115}$ Keightley ${ }^{116}$ describes this approach as being particularly advantageous to claimants because it is one that would allow the object of the socio-economic right in question (water) to be quantified. Pinning an exact figure to the quantity of water that people are entitled to '... would have meant that every person could claim the provision of a particular quantity of water from the state ...' ${ }^{117}$ The Constitutional Court, instead, chose to follow a traditional path which had been followed by the Court itself in the earlier judgments of Government of the Republic of South Africa and others $v$ Grootboom and others (hereafter Grootboom), ${ }^{18}$ and Minister of Health and others $v$ Treatment Action Campaign (TAC) and others (hereafter TAC), ${ }^{119}$ which considered the rights of access to adequate housing ${ }^{120}$ and access to health care services, respectively. In line with the approach in the foregoing cases, the Constitutional Court in casu first focused on the nature and extent of the government's obligation to provide access to water in terms of section 27. ${ }^{121}$ It found in this respect that:

Applying this approach [followed in Grootboom and TAC] to section 27(1)(b), the right of access to sufficient water, coupled with section 27(2), it is clear that the right does not require the state upon demand to provide every person with sufficient water ... rather it requires the state to take reasonable legislative and other measures progressively to realise the achievement of the right of access to sufficient water, within available resources. ${ }^{122}$

113. Keightley (n 17).

114. Space does not allow the judgment to be exhaustively canvassed in this survey but see Keightley (n 17) and De Vos (n 18).

115. See section 27(2) of the Constitution.

116. Keightley (n 17).

117. Keightley (n 17).

118. 20011 SA 46 (CC).

119. 20025 SA 721 (CC). Section 27(1)(a) of the Constitution. See C Ngwena and R Cook, 'Rights Concerning Health' in Brand and Heyns (n 7) 107-151; Liebenberg (n 8) 33-17 et seq; Jansen van Rensburg (n 68) 1/15-13/15; Davis (n 67) at 307 et seq.

120. Section 26 of the Constitution. See P De Vos, 'The Right to Housing' in Brand and Heyns (n 7) 85-106; De Vos (n 68) 258-76; Jansen van Rensburg (n 68) 1/15-13/15; Liebenberg (n 8) 33-17 et seq; D Bilchitz, 'Giving Socio-economic Rights Teeth: the Minimum Core and Its Importance' (2002) 119 SALJ 484-501; Davis (n 67) at 306 et seq.

121. Mazibuko v City of Johannesburg at para 48.

122. Mazibuko $v$ City of Johannesburg at paras 50 and 59. See also Liebenberg (n 8) 33-4. 
There was accordingly no duty on government, immediately, to realize section 27 , or in other words, immediately to provide people with a predetermined quantity of water on demand.

\subsubsection{Quantifying the right of access to water}

The Court furthermore did not see its way open to quantify the right of access to water because, again following the precedents it set itself in Grootboom and TAC, ${ }^{123}$ it rejected the idea that socio-economic rights in the South African Constitution contained a minimum core, ie '... a basic content which must be provided by the state' ${ }^{124}$ It opted rather for a more flexible approach with respect to the quantification of adequate water in terms of section 27 . It clearly stated in this respect that '.. what the right requires will vary over time and context. Fixing a quantified content might, in a rigid and counter-productive manner, prevent an analysis of context'. ${ }^{125}$ If the Court had in fact acknowledged the existence of a minimum core in terms of section 27 , this would have meant, inter alia, that the state would have been under the obligation to provide a minimum quantity of water, regardless of the qualifications and restraints imposed by the availability of resources, to provide access and to provide it within a specific period of time; ie a specific minimum quantity of water would have had to be immediately provided regardless of the availability of human and financial resources. ${ }^{126}$ The Court's interpretation here is in line with its application of the test of 'reasonableness review' described below.

\subsubsection{Reasonableness}

It is clear from the foregoing that the Court placed considerable emphasis on the need to establish the nature and extent of the government's obligation to provide access to water in terms of section 27. The Court considered in this respect that once the obligation had been established and it transpired that there was a positive obligation on the government to realize the right in question, a court would enforce this positive obligation in the following instances: if the government took no steps at all to realize the right, the court would require the government to take steps; if the government adopted certain measures but these measures were unreasonable, courts would require the measures to be reviewed to comply with the constitutional standard of

123. Liebenberg (n 8) 33-23-33-32.

124. Mazibuko v City of Johannesburg at paras 52; 53-57 and Liebenberg (n 8) 33-23; and Bilchitz (n 120) 484-501.

125. Mazibuko v City of Johannesburg at paras 60-68. The Court's unwillingness in this respect was bolstered by its undertaking not to precisely prescribe to the state what the achievement of any particular socio-economic right must entail (trias politica doctrine). Mazibuko v City of Johannesburg at paras 61-68. The reluctance of the Court is in line with its careful approach in Grootboom and TAC; any court will be extremely hesitant to dictate specific policy and legislative options to government. See further, Liebenberg (n 39) 21-22.

126. The Court rejected this obligation finding that it would be '... impossible to give everyone access even to a "core" service immediately'. Minister of Health and others v Treatment Action Campaign (TAC) and others at para 35. The Constitutional Court's consistent rejection of the notion of minimum core obligations has been strongly criticized, see Liebenberg (n 8) 33-2733-32 and Stewart (n 75) at 493. 
reasonableness (a measure would be unreasonable if, for example, it made no provision for those most desperate in need); if the government adopted a policy with unreasonable limitations or exclusions, courts would order those to be removed; if there were an obligation on the government to continually review its policies to ensure that the right in question was progressively realized and this was not done, courts might order the government to do so; or if the process followed by the government to explain its policies were flawed, or information provided by the government relating to its policies were inadequate, courts might also grant appropriate relief. ${ }^{127}$ The reasonableness challenge expressed above would mean that with respect to socioeconomic rights, '... no concrete demand can be made on the state to provide [what is stated in the right]. ${ }^{128}$ Any challenges raised with respect to socio-economic rights cannot therefore focus on the right per se, but rather on the obligation on the government to progressively realize the right. In other words, any challenge must test whether or not the state's actions have met the constitutional standard of reasonableness in the state's efforts to realize the right. A court will typically intervene only where this standard has not been met. ${ }^{129}$ It will not intervene in those instances where the state has failed to provide a specific quantity of a socio-economic entitlement such as water. This test is known as the 'reasonableness review' ${ }^{130}$ and entails that in the absence of minimum core obligations (a notion which the Constitutional Court has consistently rejected, as illustrated above), it would be required of a court only to determine whether the legislative and other measures taken by government to realize a positive obligation in terms of socio-economic rights are reasonable or not. ${ }^{131}$ The Constitutional Court found in casu that the city's Free Basic Water policy was reasonable and the policy, as a result, survived this part of the applicants' challenge. ${ }^{132}$

This test, coupled with the reluctance of the Court to determine a minimum core with respect to water, theoretically allows for a ' ... flexible, context-sensitive model of review for socio-economic rights claims' 133 and '... [it] creates the ongoing possibility of challenging socio-economic deprivations in the light of changing contexts. ${ }^{134}$ It is this latter benefit that 'reasonableness review' offers which, in my view, would be particularly apt in adjudicating socio-economic rights that also involve natural resources, such as water. This is so because the availability of water and all of the conditions which might influence this availability are highly

\section{Mazibuko v City of Johannesburg at paras 67 and 71 and Keightley (n 17).}

128. Keightley (n 17).

129. The notion of 'reasonableness' is problematic, see Bilchitz (n 120) at 495.

130. See, for example, Liebenberg (n 8) 33-33-33-41; S Liebenberg, 'Basic Rights Claims: How Responsive Is "Reasonableness Review"?' (2004) 5(5) ESR Review 7-11. 'Human dignity', both as a constitutional right (section 10 of the Constitution) and a value (section 7(1) of the Constitution), will play an important role in interpreting socio-economic rights, especially with respect to 'reasonableness review'. See, generally, Liebenberg (n 39). Equality, again as a right (section 9 of the Constitution), and as a value (section 7(1) of the Constitution), would also play a role in the interpretation of 'reasonableness review'. See Liebenberg and Goldblatt (n 8) 356-58. So too would the value of 'freedom'. See S Liebenberg, 'The Value of Freedom in Interpreting Socio-economic Rights' (2008) 1 Acta Juridica 149-70 at 165-76.

131. 'Reasonableness review' has been criticized as vague, furthermore, according to some, it fails to address the immediate needs of the most vulnerable sectors of society, see further in this respect Liebenberg (n 8) 33-38-33-41 and Liebenberg, 'Basic Rights Claims' (n 130) at 9-10. 132. Mazibuko v City of Johannesburg at paras 78-89.

133. Liebenberg (n 70) at 6.

134. Ibid. 
variable, unpredictable, and in a constant state of flux. The flexible, adaptive and accommodative interpretative model that 'reasonableness review' offers in this instance would also be particularly conducive to an environmental policy milieu, which must be equally adaptive and accommodative of the variable effects of climate change on water resources in South Africa. In short: uncertainty necessitates manoeuvrability.

\subsubsection{Prepayment meters}

In sharp contrast to the findings of the High Court and Supreme Court of Appeal, the Constitutional Court found the prepayment meters to be lawful. These meters, according to the Court, were in fact an essential part of the City's service delivery effort:

Given that the power to install pre-paid meters is one which is reasonably incidental to providing services to citizens in a sustainable manner that permits cost recovery, it is a power that is reasonably incidental to the effective performance of the functions of a municipality. ${ }^{135}$

Moreover, the installation of the meters had not resulted in unauthorized discontinuation of the water supply. 'Discontinuation' in the eyes of the Court describes a situation where 'something is made to cease to exist'. ${ }^{136}$ When a prepayment meter stops the supply of water as soon as the allowable quantity of free water is exceeded, it only temporarily suspends the water until new credit is bought, or the new monthly free basic supply commences. According to the Court, to say therefore that a prepayment meter results in access to water ceasing to exist at a certain point is incorrect. ${ }^{137}$ It concluded that neither the Free Basic Water policy nor the prepayment meters constituted a breach of section 27 of the Constitution and that, therefore, the applicants' appeal had to fail.

\subsubsection{Ecological concerns}

The ecological integrity of the water resource referred to in section 27 was never an explicit issue before any of the three courts. This is so because the courts were not required by any of the parties to deliberate on the matter. Moreover, the parties to the dispute chose not to base their claims and defences on those legal provisions related to water resource protection (including section 24 of the Constitution, the NWA and certain provisions of the WSA discussed above). This is a pity, since one can only imagine the rich contribution such an enquiry could have made to the development of environmental, and more generally, human rights law jurisprudence.

Nevertheless, in the opening paragraphs of its judgment the Constitutional Court juxtaposed the critical need to address socio-economic inequalities, the severe lack of water services and the unequal access to water resources with the fact that water resources are extremely scarce in South Africa. It recognized that access to water has long been unequal and that the task of obtaining water remains a 'tiring daily burden' for many. ${ }^{138}$ South Africa, however:

135. Mazibuko v City of Johannesburg at para 111.

136. Mazibuko $v$ City of Johannesburg at para 120.

137. This approach has been criticized by De Vos (n 18).

138. Mazibuko v City of Johannesburg at para 2. 
[a]t the same time ... is a largely arid country, often assailed by drought. Redeeming the constitutional promise of access to sufficient water for all will require careful management of a scarce resource. The need to preserve water is a responsibility that affects all spheres of government. ${ }^{139}$

In reference to the WSA, discussed above, the Court also accepted that there is a '... connection between the rights of people to have access to a basic water supply and government's duty to manage water services sustainably ${ }^{140}$ and that this connection is clearly articulated in the preamble to the WSA. ${ }^{141}$

Another instance where water resource conservation came to the fore was in the City's justification for the instalment of the prepayment meters. The meters, as seen above, were primarily meant to ensure that users of water actually pay for that service and that the frugal use of water resources is encouraged as a result. Also, more indirectly, being in a position where the costs of water service provision are actually recovered, at least to some extent, would allow the City to upgrade and maintain the water infrastructure for the continued long-term (or sustainable) benefit of present and future generations. The meters were thus intended as a method to ensure that water is used within the allowable ecological constraints of the resource including, inter alia, limited quantities and increasing costs of water provision.

That the Constitutional Court appreciated, at least to some extent, the tensions between the need to protect water resources on the one hand and the (very urgent and immediate) need to provide people with access to sufficient water on the other is clear from the foregoing. What is less clear is whether ecological considerations as such directly influenced the Constitutional Court's eventual findings. This does not seem to have been the case. One can also only speculate regarding the extent to which the Court might have been influenced by the City's arguments regarding the benefits and purpose of the prepayment meters; so too, the extent to which the scarcity of water might influence sustainable water services provision. The Court's reluctance to quantify the right to access to sufficient water seems to suggest that it was extremely wary of assuming the role of the executive branch of government (the City) by allocating specific quantities to a scarce resource. It may be that the Court recognized that in doing so it could potentially place an enormous burden on government; a burden which, given the scarcity of water resources and the impending vagaries of climate change, could have been fatal for the environmental and socio-economic governance effort in South Africa. The Court's positivistic, conservative and literal interpretation of 'discontinuation' further suggests that it might have recognized the need for a system to regulate the demand of a scarce resource. While one cannot deny people access to one of the most basic life-sustaining resources, one must, in the interest of long-term sustainability, at least impose reasonable restrictions on the use and exploitation of such resources. This, ultimately, is what sustainability demands.

\section{QUO VADIS?}

Issues related to socio-economic justice usually evoke fierce emotion. An unbiased reading of Mazibuko $v$ City of Johannesburg, therefore, would to my mind be difficult, if not impossible. My immediate inclination upon having read the judgment was

139. Mazibuko v City of Johannesburg at para 3.

140. Mazibuko $v$ City of Johannesburg at para 3.

141. See the discussion above. 
to side with Phiri's poor and to join the chorus of critics who have lambasted the Court for its 'disappointing' judgment. They are right to do so, for without constructive criticism the South African Bill of Rights would be worth only the paper it is written on and it would remain a paper tiger in the struggle to achieve socio-economic justice. It was only upon rereading the judgment many times that I realized the contribution the Constitutional Court's decision could make to the sustainability debate in South Africa. Where does this contribution lie?

More than anything else, Mazibuko in my view is a tangible example of the conflicts involved in considerations of the notion of sustainability. ${ }^{142}$ The case raises difficult questions while answers are not readily forthcoming. Can one ignore the plight of the poor in the interest of protecting water resources? Obviously this would not be permissible in a constitutional state such as South Africa, which is founded on the constitutional values of human dignity, equality, the advancement of human rights and freedoms, non-racialism and non-sexism. ${ }^{143}$ Moreover, given the transformative purpose and role that socio-economic rights have in South Africa of guaranteeing the provision of the basic conditions of human welfare, such an approach might even run counter to prevailing constitutional values, ideals and objectives. What would be important, in my view, is to acknowledge that the process of achieving socioeconomic justice, together with all other constitutional values, ideals and objectives, is not a short-term one. Instead, it is a process the success of which hinges on the achievement of a long-term ideal, distinctly nestled in the sustainability governance paradigm of inter-generational equity. ${ }^{144} \mathrm{Had}$ the Constitutional Court allowed every person access to 50 litres of free water per day, it might very well have achieved short-term intra-generational equity by providing the residents of Phiri access to sufficient water. However, in the likely event of South Africa's water resources becoming increasingly restricted in future, it is doubtful that there would be enough water to realize these very same constitutional entitlements that the children and grandchildren of Phiri's residents might also have in future. The difficulties that inter-generational equity invokes in this respect are compounded by the uncertainty of forecasting the impacts of climate change. Evidence suggests that the poor will be those most severely affected by climate change and it is almost certain that the availability of water resources will be severely impacted. From a sustainability and specifically inter-generational equity perspective, therefore, short- or medium-term solutions are inappropriate. A long-term strategy would be required that should aim to provide people in the present generation with some water while simultaneously encouraging the sparse and prudent use of water for the benefit of future generations too. The Constitutional Court's decision is one that would essentially give effect to such a strategy and therefore, in contrast with the decisions of the High Court and the Supreme Court of Appeal, is one which has the potential to create decision-making or governance opportunities more conducive to long-term sustainability.

The judgment also shows that environmental protection can be achieved through judicial avenues, even in those instances where parties to the dispute do not expressly invoke those provisions of the law specifically aimed at environmental protection.

142. See also Stewart and Horsten (n 106) 486-505.

143. Constitution, section 1. Furthermore the South African environmental law regime is explicitly premised on an anthropocentric approach. See, for example, section 24 discussed above, and the framework provisions of the National Environmental Management Act 107 of 1998. 144. See for example LM Collins, 'Revisiting the Doctrine of Intergenerational Equity in Global Environmental Governance' (2007) 30(1) Dalhousie Law Journal 79-140. 
South African law provides for an environmental right and, in the case of water resources, the NWA, which could be employed to safeguard the ecological aspects of water. Unfortunately, none of these provisions was relied on by the parties in Mazibuko. The Court managed, possibly unintentionally, to 'protect' water resources through a more restrictive, conservative or positivistic interpretation of the socioeconomic right that relates to water. This is significant for two reasons. First, socio-economic rights traditionally are considered entitlements to realize the basic conditions of human welfare and to guarantee these entitlements. The manner in which the right of access to water was interpreted in Mazibuko, however, suggests that the possibility exists for certain socio-economic rights to place restrictions on the unbridled and unsustainable use of natural resources to satisfy immediate basic demands. Provided that these rights exist in a constitution and that they are interpreted by the judiciary with the necessary care and with a long-term view (read: 'conservative'), it would arguably be possible to safeguard natural resources for the benefit and use of present and future generations even where a constitution does not provide for explicit environmental rights. While section 27 has been incorporated in the Constitution to provide for equality and, more specifically, socio-economic justice, Mazibuko arguably has opened the door to the possibility of using the right in future to more directly 'regulate' access to water, and thereby to better protect water resources. In short, a conservative approach to the interpretation of certain socioeconomic rights may allow for the possibility of protecting natural resources through the imposition of constraints or limitations on resource use provided by the concept of sustainability. Second, there is little doubt that climate change will lead to all sorts of intra- and inter-generational inequities, and that it will, for instance, have extreme impacts on the socio-economic conditions of people by affecting the environmental resources available to them. While the provision of environmental rights may be best suited to safeguarding environmental resources, those rights may not always be sufficiently sensitive to and accommodative of the socio-economic needs of people. Socio-economic rights, on the other hand, are by definition people-centred and, provided they are restrictively interpreted, may therefore be very well placed to address some of the inter- and intra-generational socio-economic inequalities and environmental consequences resulting from climate change.

If anything, Mazibuko highlights the urgency of South Africa's 'water problem', a problem that is exacerbated by poverty, inequality, a sense of present and future environmental risks, and a myriad of uncertainties. The facts in Mazibuko illustrate that the country is barely capable of dealing with existing socio-economic and environmental (sustainability) challenges. Considering that all predictions point to these conditions worsening over time as a direct result of climate change, the country does not seem to be adequately prepared to tackle these future challenges effectively. To date, South Africa has virtually no tangible legal provisions directly dealing with climate change, and it would accordingly be possible to use only indirect existing mechanisms, including, inter alia, sections 24 and 27, the NWA and the WSA, to address water resource protection and water demand and supply-side management in the context of climate change. Immediate priorities in this respect may include the adoption of an extensive policy and then legislation dealing with climate change generally. This policy and legal framework must, among others, address climate change preparedness, and adaptation strategies and responses, not only to the ecological impacts of climate change, but also to the socio-economic impacts on all sectors of South African society. Specific policies and laws must also then be formulated to specifically address sustainable water resource management in the context of climate change. By not being overtly 
prescriptive to government in Mazibuko, at least with respect to water resources and water services provision, the Constitutional Court has allowed decision-makers considerable scope regarding the manner of water resources protection and quantity of water that must be factored into future strategies. They should be commended for doing so.

\section{CONCLUSION}

No reasonable person can or should ignore the plight of the poor. Likewise, ignoring the prudent and sustainable use of finite resources now would be tantamount to ignoring the future needs of the poor. Where socio-economic rights adjudication is concerned, when it involves finite natural resources, such as water, which are set to become severely limited in future, a conservative approach might very well be warranted with respect to the satisfaction of immediate needs. Sustainability implies a conservative use of resources and while it also alludes to the promotion of socio-economic interests and immediate basic needs, this can be done only in so far as these resources will be available to satisfy future socio-economic demands. While 25 litres of free water per person per day may be too little, from an ecological point of view 42 or 50 litres may be too much. In these uncertain times it seems critical to endorse the Constitutional Court's cautious, and in my view, ecologically responsible approach in Mazibuko, an approach, despite it not having been directly invoked by the Court, which seems to suggest that sustainability demands that '.. a risk-averse and cautious approach is applied, which takes into account the limits of current knowledge about the consequences of decisions and actions'. ${ }^{145}$ Only such a cautious approach will ensure that there is some water, for all, forever. ${ }^{146}$

145. This is the precautionary principle or approach under s2(4)(a)(vii) of the South African National Environmental Management Act 107 of 1998.

146. 'Some for all forever' is the notion that informed the formulation of South Africa's water law and policy framework, specifically, the NWA and the WSA. See J Harris, HR Van Vliet and HM MacKay, 'Water Resource Quality Policy: the Approach Adopted by the Department of Water Affairs and Forestry under the Water Law Principles' (1999) 39(10/11) Wat Sci Tech $31-37$. 